UDC (519.87-032.1:621.5.041):622.45

O.V.Zamytskyi, Dr. Sc. (Tech.), Prof., orcid.org/0000-0002-8113-6369,

B. M. Litovko, Cand. Sc. (Tech.), Assoc. Prof., orcid.org/0000-0002-9055-4984,

M.Yu. Lider, orcid.org/0000-0003-3780-9076, M. I. Shepelenko, orcid.org/0000-0002-5104-7074
DOI: $10.29202 / \mathrm{nvngu} / 2019-3 / 8$

State Higher Educational Institution "Kryvyi Rih National University”, Kryvyi Rih, Ukraine, e-mail: azam@i.ua

\title{
MATHEMATICAL MODELING OF THE PROCESS OF COMPRESSED AIR FLOWING THROUGH THE PIPELINE AS AN ELEMENT OF THE PNEUMATIC NETWORK
}

Purpose. Improvement of the effectiveness of mining equipment operation due to accuracy increase in calculations of a compressed air parameters at design of pneumatic network.

Methodology. Theoretical and empirical methods of research were used in the paper. Mathematical modeling of thermohydrogasdynamic processes at a compressed air flow through the pipeline is carried out. Methods of mathematical statistics were used.

Findings. Mathematical modeling of a compressed air flow through the pipeline when the air temperature is above ambient temperature, coming with a heat rejection to the ambient air and throttling due to pipe resistance is carried out. In this case, change in air conditions in the flow depends on a ratio of the temperature change caused by heat rejection and pressure because of pipe resistance. Dependences of change in temperature and pressure of the compressed air through the pipeline length are obtained.

Exploratory tests and results of numerical calculations confirmed adequacy of mathematical models of a compressed air flow through pneumatic pipeline.

Originality. New dependences for determination of pressure and temperature of compressed air considering change in the heat-transfer coefficient through pneumatic pipeline are obtained.

Practical value. The use of the received dependences when designing pneumatic networks of mines allows providing generation of compressed air with necessary parameters for uninterrupted pneumatic supply of the mining equipment of mines.

Keywords: mine pneumatic network, compressed air, compressor systems, pipeline, compressed-air installation, mathematical modeling, computing experiment

Introduction. The compression facilities make a considerable part of cost of enterprise fixed assets. Its profitability depends on effective operation of the compressor system: increase in costs of generation of compressed air reduces a profitability ratio of the enterprise, while increase in productivity of the compressor system and decrease in unproductive losses of air improve this indicator.

Considerable influence on profitability of the compressor system is provided by electricity saving on generation of compressed air, reduction of losses of air when transporting to consumers and its rational use for production purposes [1].

Basic causes of unsatisfactory operation of compressor stations are losses of compressed air because of the underestimated productivity of compressor machines, compressed air losses in air ducts, pneumatic mechanisms and isolation valves, as well as considerable power consumption on the drive of the compressor system and processing equipment that is an integral part of compression facilities. Therefore, reduction of power consumption in compressor systems is one of the fundamental tasks which need to be solved.

In mining industry use of pneumatic energy is the most effective at coal pits and mines which are dan-

(C) Zamytskyi O. V., Litovko B. M., Lider M. Yu., Shepelenko M. I., 2019 gerous because of gas and dust. The efficiency of application of this type of energy is substantially defined by compliance of calculated parameters of pneumatic network and operating performance of the used equipment and compressor station. The complexity of the physical processes arising at transportation of compressed air through the pipeline from the compressor system to consumers of pneumatic energy reduces the accuracy of prospective calculations of metering characteristics of the pneumatic transport system.

The mine pneumatic network represents the extensive piping system which is used for transportation of compressed air from the compressor station to points of consumption.

The pneumatic network is the point of the biggest losses of energy at operation of mine compressed air installations; therefore, the correct design of pneumatic network is a condition of effective operation of the pneumatic equipment.

Literature review. The studies widely cover the issues of improving mining equipment operation in works by V. I. Samusia.

In the article [2] the analysis of real exploitation conditions of the "vessel - reinforcement" systems in vertical shafts is executed, recommendations providing the necessary increase in operating strength security of 
hoisting plants for the shafts with the broken geometry are presented.

The paper [3] reviewed the results of the experimental research of the heat pump plant showing that the measured values of the volume flow rate of the heat transfer agent in the circuits, temperatures and plant's heat rate well agreed with the calculated values.

The article [4] contains the results of experimental research of unstable aeroelasticity type of wind resonance and galloping for the elements of pipeline of deep-water hydraulic handling. The experiments were carried in aerodynamic pipe on scale models while using the strain measure balance.

According to a research of the EU ("Compressed air systems in the European Union"), in $80 \%$ of all enterprises the systems of compressed air distribution are the weak spot in the compressed air technology. The existing and applied methods of calculation of compressed air pneumatic pipeline are based on use of empirical dependences and do not fully correspond to the valid processes which arise at operation of pneumatic networks at the underground enterprises. As a result, in most cases compressor stations work with insufficient or excess values of operating pressure and consumption.

The detailed overview of production process, transportation and use of compressed air in the different industries are provided in the studies $[5,6]$.

The study [7] describes performed numerical research on vibration impact on a cylindrical pipe with gas in it. Edges of a pipe are provided with the continuous temperature which is equal to the initial temperature. A value of a heat flow through pipe walls with different vibratory frequencies is obtained.

There are developed mathematical models [8], where pressure and mass air flow rate are chosen as the main variables for the description of a pneumatic system, but they do not consider dependence of change in the heat-transfer coefficient on decrease in temperature of compressed air when moving along the pipeline.

The study [9] is based on the research on influence of a cooling water temperature on economic efficiency of heat-pumping technology of heat recovery of compressor plants at mining plants. The mode when the specific cost of compressed air development is the smallest is defined.

With use of laws of thermogasdynamics, there is developed a numerical method for requirements of obtaining dew point temperature and amount of the condensate precipitated out longwise air piping of pneumatic network from the compressor to a mine trunk [10].

As a rule, air-delivery systems of the industrial enterprises are individual. It is explained by a company profile, planning solutions of the enterprise, type of work (interchangeability, seasonality), type and characteristics of the pneumatic equipment, the mode of its work (constant, periodic, accidental), control and automation degree, and others.

Generally, the principles of development of mathematical models are universal, but research and optimization of system work are carried out only for a specific network which is assigned. In the study [11] there is offered a mathematical model of an air delivery system of an industrial enterprise which consists of sub-models and elements and each of them is described by a system of equations and inequalities with corresponding assumptions and terminations. The model is made for calculation of network parameters and the choice of the rational modes of its work. The choice of rational modes of compressor plant operation is carried out on the simplified example of the air delivery system of the industrial enterprise by means of the developed model.

The paper [12] discusses the results of theoretical and pilot studies on the dynamic processes happening in compressed air hydro-pneumatic accumulators of mines and pits. There is substantiated a hydro-pneumatic accumulator design that allows stabilizing and increasing pressure in mine pneumatic network in comparison with pressure of the compressed air coming from the compressor station.

However, the mentioned above studies do not consider dependence of change in heat-transfer coefficient on decrease in temperature of compressed air while moving through the pipeline, which reduces the accuracy of calculations.

Thus, it is possible to make a conclusion that the modern accumulated data, new research studies, increase in computer capacities and a possibility of data acquisition in real time due to modern measuring devices allowed studying extensively a problem of a compressed air flow in pipeline pneumatic systems. However, many studies devoted to development of this subject, development of a mathematical apparatus and its program implementation do not solve this problem fully. Therefore, development of a mathematical model of process of compressed air flow through pipelines is a relevant scientific task, whose solution will increase overall operation of mine pneumatic network.

Purpose. The purpose of the work is to carry out mathematical modeling of hydro- and thermodynamic processes of compressed air flow through pipelines as elements of pneumatic network.

The task is set to develop a mathematical model describing the compressed air flow in pneumatic network, to conduct pilot studies on this model and check the obtained results by numerical calculations.

Methods. Variety and complexity of the physical processes proceeding in pipelines and connected with the features of hydrodynamics and thermodynamics of the compressed air flow with the availability of accidental influences, point to outstanding complexity of the analysis task of such flow in pipelines as elements of pneumatic network. The existing and traditional methods of calculation of compressed air pipelines are based on use of empirical dependences and they do not fully correspond to the valid processes which arise at operation of pneumatic networks at the underground enterprises. As a consequence, in most cases compressor stations work with insufficient or excess values of operating pressure and consumption.

In this regard, the special relevance is acquired by mathematical modeling of the considered processes. Use of modern computer technologies allows expanding a concept of mathematical modeling, implementing it as a part of a computing experiment. 
The moving of the compressed air flow through the pipeline, when the air temperature is higher than the ambient temperature, is followed by heat rejection to the environment and throttling of air at the expense of pipeline resistance. In this case, a change in air parameters in a flow depends on a ratio of the changes in temperature caused by heat extraction and pressure because of pipeline resistance.

At the first stage of modeling, it is reasonable to accept that dry compressed air moves through the pipeline. Then, according to the equation of a heat balance for the section of the pipeline, it is possible to write down the differential equation

$$
G \cdot C_{p} \cdot d t=-k_{x} \cdot\left(t-t_{H}\right) \cdot \pi \cdot d x
$$

where $G$ is a mass air flow rate, $\mathrm{kg} / \mathrm{s} ; C_{p}$ is the specific heat capacity of air, $\mathrm{J} / \mathrm{kg} \cdot{ }^{\circ} \mathrm{C} ; k_{x}$ is a linear heat transfer coefficient from a compressed air flow to the environment, $\mathrm{W} / \mathrm{m} \cdot{ }^{\circ} \mathrm{C} ; t_{\mathrm{H}}$ is the ambient temperature, ${ }^{\circ} \mathrm{C} ; t$ is the air temperature in the pipeline, ${ }^{\circ} \mathrm{C}$.

The linear heat transfer coefficient which enters into the (1) is found by a formula

$$
k_{x}=\frac{1}{\frac{1}{\alpha_{1} \cdot d_{1}}+\frac{1}{2 \lambda} \cdot \ln \frac{d_{2}}{d_{1}}+\frac{1}{\alpha_{2} \cdot d_{2}}},
$$

where $d_{1}, d_{2}$ are the inside and outer diameters of the pipeline, $\mathrm{m} ; \alpha_{1}, \alpha_{2}$ are the heat transfer coefficients from internal and outer side of the pipeline, respective$\mathrm{ly}, \mathrm{W} / \mathrm{m}^{2} \cdot{ }^{\circ} \mathrm{C} ; \lambda$ is the coefficient of heat conductivity of the pipeline wall, $\mathrm{W} / \mathrm{m} \cdot{ }^{\circ} \mathrm{C}$.

During the moving of air in pipes and on the basis of experiments on studying of heat emission there was determined generalized dependence

$$
\alpha_{1}=0.018 \cdot \frac{\lambda_{1}}{v_{1}^{0.8}} \cdot \frac{\omega_{1}^{0.8}}{d_{1}^{0.2}},
$$

where $\lambda_{1}$ is the coefficient of heat conductivity of air in the pipeline, $\mathrm{W} / \mathrm{m} \cdot{ }^{\circ} \mathrm{C} ; d_{1}$ is the inside diameter of the pipeline, $\mathrm{m} ; \mathrm{v}_{1}$ is the kinematic coefficient of viscosity, $\mathrm{m}^{2} / \mathrm{s} ; \omega_{1}$ is the flow rate of compressed air, $\mathrm{m} / \mathrm{s}$.

The coefficient from outer side of the pipeline which enters into the formula (2) is connected with free convection and it is found for horizontal pipes by a formula

$$
\alpha_{2}=\frac{\mathrm{Nu}_{2} \cdot \lambda_{2}}{d_{2}}
$$

where $\mathrm{Nu}_{2}=0.46 \cdot G r^{0.25}$ is the Nusselt number; $G r=\frac{\beta \cdot d_{2}^{3} \cdot g \cdot \Delta t_{2}}{v_{2}^{2}}$ is the Grashof number; $\beta=\frac{1}{T_{H}}$ is the temperature coefficient of volume expansion, $1 / \mathrm{K} ; T_{H}$ is the absolute temperature of environmental air, $\mathrm{K} ; \mathrm{g}$ is acceleration of gravity, $\mathrm{m} / \mathrm{s}^{2} ; \mathrm{v}_{2}$ is the kinematic coefficient of viscosity of environmental air, $\mathrm{m}^{2} / \mathrm{s} ; \Delta t_{2}=t_{2}-t_{H}$ is temperature pressure between the wall and environment air, ${ }^{\circ} \mathrm{C}$.

Using $\mathrm{Gr}$ and $\mathrm{Nu}_{2}$ in (3), we will receive a formula for calculation of heat-transfer coefficient from the outer side of the pipeline

$$
\alpha_{2}=0.814 \cdot \lambda_{2} \cdot\left(\frac{\beta \cdot \Delta t_{2}}{v_{2}^{2} \cdot d_{2}}\right)^{0.25}
$$

The analysis of rates of temperature and pressure differences raises the possibility, at the first stage of mathematical modeling, of accepting the heat transfer coefficient rate from the inside of the pipeline as a constant.

Then, taking into account the fact that the constant thermal condition of the pipeline is considered, it is possible to write down equality of heat flows which is given by the hot and taken by the cold environment, as

$$
\frac{\Delta t}{A+B \cdot\left(\Delta t_{2}\right)^{-1 / 4}}=\frac{\left(\Delta t_{2}\right)^{5 / 4}}{B},
$$

where $A=\frac{1}{\alpha_{1} \cdot d_{1}}+\frac{1}{2 \lambda} \cdot \ln \frac{d_{2}}{d_{1}} ; B=\frac{1.229}{\lambda_{2} \cdot d_{2}} \cdot\left(\frac{v_{2}^{2} \cdot d_{2}}{\beta}\right)^{0.25}$.

The equation (4) allows showing the general temperature pressure through the temperature pressure on the external wall of the pipeline

$$
\Delta t=\frac{A}{B} \cdot\left(\Delta t_{2}\right)^{5 / 4}+\Delta t_{2} .
$$

Considering (4), the equation (1) can be written down as

$$
G \cdot C_{p} \cdot \frac{d(\Delta t)}{d x}=-\frac{\pi \cdot \Delta t}{A+B \cdot\left(\Delta t_{2}\right)^{-1 / 4}}
$$

Further for availability of calculations we will make a replacement

$$
y=\left(\Delta t_{2}\right)^{1 / 4} \text {. }
$$

Then we will write down (5) as

$$
\Delta t=\frac{A}{B} \cdot y^{5}+y^{4} .
$$

Taking into account (7) and (8) equations, (6) can be written as

$$
\frac{d y}{d x}=-\frac{\pi}{G \cdot C_{p}} \cdot \frac{y^{2}}{5 A y+4 B} .
$$

The solution (9) is found by integration

$$
5 A \cdot \ln \left(\frac{y}{y_{0}}\right)-4 B \cdot\left(\frac{1}{y}-\frac{1}{y_{0}}\right)=-\frac{x \cdot \pi}{G \cdot C_{p}},
$$

where $y_{0}$ is the value of the variable on an entrance to the pipeline.

It is reasonable to write down the equation (10) in a dimensionless form

$$
E \cdot \ln \left(\frac{y_{0}}{y}\right)+\frac{F}{y_{0}} \cdot\left(\frac{y_{0}}{y}-1\right)=\xi
$$

where $E=\frac{5 A \cdot G \cdot C_{p}}{\pi \cdot l} ; \quad F=\frac{4 B \cdot G \cdot C_{p}}{\pi \cdot l} ; \xi=\frac{x}{l} ; l$ is the length of the pipeline, $\mathrm{m}$.

ISSN 2071-2227, Naukovyi Visnyk NHU, 2019, № 3 
Then the equation (8) will take the following form

$$
\Delta t=0.8 \cdot \frac{E}{F} \cdot y^{5}+y^{4} .
$$

Finding of the value $y_{0}$ is connected with the numerical solving of the equation when $\Delta t=\Delta t_{0}$

$$
0.8 \cdot \frac{E}{F} \cdot y_{0}^{5}+y_{0}^{4}=\Delta t_{0} .
$$

At a set value $x$ by the numerical solving of the transcendental equation (11) there is a size $y$. After substituting this value in the equation (12), we find the required value of the compressed air temperature at a distance $x$ from the beginning of the pipeline

$$
t=t_{H}+0.8 \cdot \frac{E}{F} \cdot y^{5}+y^{4},
$$

where $t_{H}$ is the temperature of environmental air, ${ }^{\circ} \mathrm{C}$.

Results. Thus, the general the solution of the equations (13, 11 and 12) allows solving the problem of change in compressed air temperature in the pipeline. The analysis of the equations (11-13) shows that at the chosen distance from the beginning of the pipeline drop in the temperature of compressed air $(\Delta t)$ depends only on two parameters $E$ and $F$, which include the pipeline sizes and also thermal-physical characteristics of the air in and outside the pipeline.

Change in pressure of the compressed air flow, caused by pipeline resistance, can be defined from the equation of Bernoulli where dissipative losses submit to Darcy law

$$
\frac{1}{\rho} \cdot \frac{d p}{d x}=-\lambda \cdot \frac{\omega^{2}}{2 d_{1}},
$$

where $\lambda_{0}$ is the Darcy factor; $\rho$ is air density in the pipeline, $\mathrm{kg} / \mathrm{m}^{3} ; \omega$ is the speed of air, $\mathrm{m} / \mathrm{s} ; P$ is air pressure in the pipeline, $\mathrm{Pa}$.

For mine conditions, the Darcy factor can be determined by a formula

$$
\lambda_{0}=\frac{0.016}{d_{1}^{0.3}} .
$$

Considering the invariance of the mass air flow rate ( $G=$ const) flow rate of the compressed air at the constant section of the pipeline is found with a formula

$$
\omega=\frac{4 G}{\pi \cdot d_{1}^{2}} \cdot \frac{1}{\rho},
$$

where $\rho$ is the current density of the compressed air, $\mathrm{kg} / \mathrm{m}^{3}$; the density of compressed air submits to ClapeyronMendeleev law

$$
\rho=3.488 \cdot 10^{-3} \cdot \frac{P}{T},
$$

where $P, T$ are the current pressure and absolute temperature of compressed air, respectively, $\mathrm{Pa} ; \mathrm{K}$.

Using (17, 16 and 15$)$ in (14) we will receive the differential equation describing change in the compressed air pressure along the pipeline depending on its temperature

$$
\frac{d p}{d x}=-3.718 \cdot \frac{G^{2}}{d_{1}^{5.3}} \cdot \frac{T}{P}
$$

Taking into account that

$$
T=\Delta t+T_{H},
$$

where $T_{H}$ is the absolute temperature of environmental air, K.

According to the formula (12), it is possible to write down the following

$$
T=T_{H}+0.8 \cdot \frac{E}{F} \cdot y^{5}+y^{4} .
$$

Applying (19) to (18), we will receive

$$
\frac{d p}{d x}=-3.718 \cdot \frac{G^{2}}{d_{1}^{5.3}} \cdot \frac{1}{P} \cdot\left(T_{H}+0.8 \cdot \frac{E}{F} \cdot y^{5}+y^{4}\right) .
$$

Using (11), we find

$$
d x=-l \cdot\left(\frac{E}{y} \cdot \frac{F}{y^{2}}\right) \cdot d y
$$

Then the differential equation (20) with (21) takes a form

$$
P \cdot d P=3.718 \cdot \frac{G^{2} \cdot l}{d_{1}^{5.3}} \cdot\left(T_{H}+0.8 \cdot \frac{E}{F} \cdot y^{5}+y^{4}\right) \cdot\left(\frac{E}{y} \cdot \frac{F}{y^{2}}\right) \cdot d y .
$$

Removing the brackets, we obtain

$P \cdot d P=3.718 \cdot \frac{G^{2} \cdot l}{d_{1}^{5.3}} \cdot\left(\begin{array}{l}\frac{T_{H} \cdot E}{y}+\frac{T_{H} \cdot F}{y^{2}}+\frac{0.8 E^{2}}{F} \cdot y^{4}+ \\ +1.8 y^{3}+F \cdot y^{2}\end{array}\right) \cdot d y$.

Integrating the last equation, we obtain dependence of the pressure of compressed air in the pipeline on parameter $y$,

$$
\left.\left.P=\left(P_{0}^{2}+\frac{7.436 \cdot G^{2} \cdot l}{d_{1}^{5.3}} \cdot\left(\begin{array}{l}
T_{H} \cdot E \cdot \ln \left(\frac{y}{y_{0}}\right)+ \\
+\frac{T_{H} \cdot F}{y_{0}} \cdot\left(1-\frac{y_{0}}{y}\right)+ \\
+\frac{0.16 \cdot E^{2} \cdot y_{0}^{5}}{F} \times \\
\times\left(\left(\frac{y}{y_{0}}\right)^{5}-1\right)+ \\
+0.45 \cdot E \cdot y_{0}^{4} \times \\
\times\left(\left(\frac{y}{y_{0}}\right)^{4}-1\right)+ \\
+\frac{F \cdot y_{0}^{3}}{3} \cdot\left(\left(\frac{y}{y_{0}}\right)^{3}-1\right.
\end{array}\right)\right)^{1 / 2}\right)\right)^{2}
$$

where $P_{0}$ is the compressed air pressure on the entrance to the pipeline, $\mathrm{Pa}$. 
Setting value $x, y$ by solving the equation (11) with (13), we find $y$, which after using in (22) determines the pressure of compressed air at distance $x$ from the entrance to the pipeline.

Numerous calculations were carried out with the formulas obtained. For an expense of a compressed air of $V=$ $=8 \mathrm{~m}^{3} / \mathrm{s}$ through the pipeline with diameter of $d_{1}=0.4 \mathrm{~m}$ with an entrance pressure of a compressed air of $P_{0}=$ $=0.7 \mathrm{MPas}$, entrance temperature of $t_{0}=80^{\circ} \mathrm{C}$ and environmental air temperature of $t_{H}=20^{\circ} \mathrm{C}$ at $l=1000 \mathrm{~m}$ distance from compressor station, there was received temperature drop $\Delta t=32^{\circ} \mathrm{C}$, and pressure loss $\Delta P=0.15 \cdot 10^{5}$ Pas.

The mathematical modeling of the compressed air flow which is carried out above belonged to horizontally located pipeline. In case of a vertical arrangement of the pipeline the heat transfer coefficient from the outer side of the pipeline $\alpha_{2}$ is calculated by a formula

$$
\alpha_{2}=\frac{N u_{2} \cdot \lambda_{2}}{l}
$$

where $N u_{2}=0.133 \cdot G r^{1 / 3} ; G r=\frac{\beta \cdot l^{3} \cdot g \cdot \Delta t_{2}}{v_{2}^{2}} ; l$ is the length of the vertical pipeline, $\mathrm{m}$.

The sense of other designations matches with accepted in (3).

After applying $\mathrm{Gr}$ and $\mathrm{Nu}_{2}$ to a formula (23), we receive

$$
\alpha_{2}=0.285 \cdot \lambda_{2} \cdot\left(\frac{\beta}{v_{2}^{2}}\right)^{1 / 3} \cdot\left(\Delta t_{2}\right)^{1 / 3} \text {. }
$$

Taking into account that steady established thermal condition of the pipeline is considered, it is possible to write down the equation similar to (4)

$$
\frac{\Delta t}{A+B_{1} \cdot\left(\Delta t_{2}\right)^{-1 / 3}}=\frac{\left(\Delta t_{2}\right)^{4 / 3}}{B_{1}}
$$

where $A=\frac{1}{\alpha_{1} d_{1}}+\frac{1}{2 \lambda} \cdot \ln \frac{d_{2}}{d_{1}} ; \quad B_{1}=\frac{3.512}{\lambda_{2} d_{2}} \cdot\left(\frac{v_{2}^{2}}{\beta_{2}}\right)^{1 / 3}$.

Then the general temperature drop is expressed through the temperature pressure on the external wall of the pipeline

$$
\Delta t=\frac{A}{B_{1}} \cdot\left(\Delta t_{2}\right)^{4 / 3}+\Delta t_{2}
$$

Taking into account (24), equation (1) takes a form

$$
G \cdot C_{p} \frac{d(\Delta t)}{d x}=-\frac{\pi \cdot \Delta t}{A+B_{1} \cdot(\Delta t)^{-1 / 3}}
$$

For convenience of calculations we will make substitution

$$
z=\left(\Delta t_{2}\right)^{1 / 3} \text {. }
$$

Then (24) and (25) will be written as

$$
\Delta t=\frac{A}{B_{1}} \cdot z^{4}+z^{3}
$$

$$
\frac{d z}{d x}=-\frac{\pi}{G \cdot C_{p}} \cdot \frac{z^{2}}{4 A z+3 B_{1}} .
$$

Integrating the differential equation (27), we find the solution in the form of private integral

$$
4 A \cdot \ln \left(\frac{z_{0}}{z}\right)+3 B_{1} \cdot\left(\frac{1}{z}-\frac{1}{z_{0}}\right)=\frac{\pi \cdot x}{G \cdot C_{p}},
$$

where $z_{0}$ is value $z$ on the entrance to the pipeline.

The equation (28) can be written down in a dimensionless form

$$
E_{1} \cdot \ln \left(\frac{z_{0}}{z}\right)+\frac{F_{1}}{z_{0}} \cdot\left(\frac{z_{0}}{z}-1\right)=\xi
$$

where $E_{1}=\frac{4 A \cdot G \cdot C_{p}}{\pi \cdot l} ; F_{1}=\frac{3 B_{1} \cdot G \cdot C_{p}}{\pi \cdot l} ; \xi=\frac{x}{l} ; l$ is the length of the pipeline, $\mathrm{m}$.

Then the equation (26) takes a form

$$
\Delta t=0.75 \cdot \frac{E_{1}}{F_{1}} \cdot z^{4}+z^{3} .
$$

Finding of the value $z_{0}$ is connected with the solution of the equation (30) at $\Delta t=\Delta t_{0}$

$$
0.75 \cdot \frac{E_{1}}{F_{1}} \cdot z_{0}^{4}+z_{0}^{3}=\Delta t_{0} .
$$

As well as in a case of a horizontal arrangement of the pipeline, there numeral equations (31, 29 and 30) are consistently solved to find the compressed air temperature at preset values $x$ and $\Delta t_{0}$. Then, the required temperature of compressed air is determined by a formula

$$
t=t_{H}+0.75 \cdot \frac{E_{1}}{F_{1}} \cdot z^{4}+z^{3} .
$$

Considering a vertical arrangement of the pipeline, the formula (14) takes a form

$$
\frac{1}{\rho} \cdot \frac{d P}{d x}=-\lambda_{0} \cdot \frac{\omega^{2}}{2 d_{1}}-g
$$

where $g$ is the acceleration of gravity, $\mathrm{m} /{ }^{2}$.

In view of the fact that the dissipative losses considerably exceed change in potential energy in the considered conditions of the compressed air flowing, it is possible to neglect the addend in the equation (33). It will allow simplifying the solution of the equation (33) for the purpose of obtaining an analytical formula.

According to the provided notes on features of the compressed air flowing in horizontal pipes, the equation (33) takes a form

$$
\frac{d P}{d x}=-3.718 \cdot \frac{G^{2}}{d_{1}^{5.3}} \cdot \frac{T}{P} .
$$

Considering that according to (32)

$$
T=T_{H}+0.75 \cdot \frac{E_{1}}{F_{1}} \cdot z^{4}+z^{3},
$$

ISSN 2071-2227, Naukovyi Visnyk NHU, 2019, № 3 
we obtain for (34)

$$
\frac{d P}{d x}=-3.718 \cdot \frac{G^{2}}{d_{1}^{5.3}} \cdot \frac{1}{P} \cdot\left(T_{H}+0.75 \cdot \frac{E_{1}}{F_{1}} \cdot z^{4}+z^{3}\right)
$$

Using (29), we find

$$
d x=-l \cdot\left(\frac{E_{1}}{z}+\frac{F_{1}}{z^{2}}\right) d z .
$$

Applying (36) to (35) and integrating the differential equation obtained, we receive dependence of the compressed air pressure in the vertical pipeline from parameter $z$

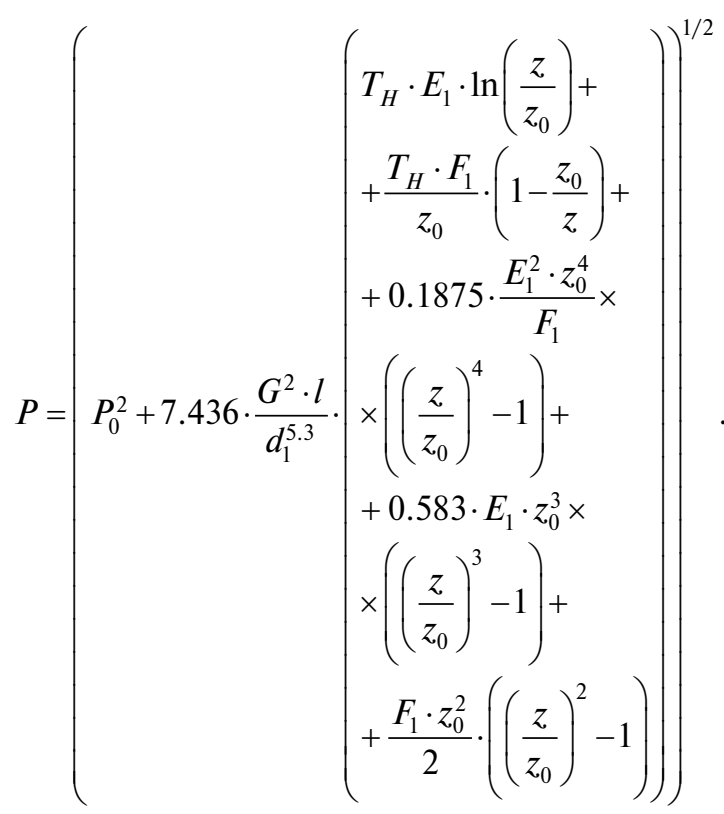

The numerical calculations given for the data which were used for the horizontal pipeline by formulas $(31,28$, 30,37 and 24) for vertical layout pipeline we gave temperature drop $\Delta t=24^{\circ} \mathrm{C}$, pressure loss of $0.36 \cdot 10^{5}$ Pas.

Discussion of research results. The adequacy of mathematical model was checked by comparison of calculation results with the measurements taken earlier at VAT Kryvorizkyi zaliznorudnyi kombinat "Kryvorizhstal”, JSC Kryvorizkyi iron ore plant "Kryvorizhstal", namely on the main pneumatic pipeline of the compressor station and mine shaft pneumatic pipeline. Results of experiments showed good convergence, the deviation made no more than $7.5 \%$ for temperature and $8.3 \%$ for pressure. It is reasonable to use the dependences obtained when calculating long pipelines $(l / D>2500)$ and at a difference of temperatures of air compression and the environment for more than $30{ }^{\circ} \mathrm{C}$. The peculiarity of this model, as opposed to the existing ones, is that it considers change in heat transfer coefficient along the pipeline, which increases the accuracy of calculations at design of mine pneumatic circuits and allows improving pneumatic supply of the mining equipment.

Conclusions.

1. The performed mathematical modeling of the compressed air flowing in pneumatic network allowed receiving new dependences for determination of pres- sure and temperature of compressed air taking into account change in heat transfer coefficients longwise of the pneumatic pipeline, which allows increasing the accuracy of calculations when designing pneumatic networks of mines.

2. Pilot studies and results of numerical calculations confirmed adequacy of the mathematical model describing the compressed air flowing in pneumatic network.

3. Further research will be directed to use of the dependences obtained to find rational parameters of final air coolers of compressor stations, which will allow increasing energy efficiency of compressed air production in mine compressor systems.

\section{Reference.}

1. Bondarenko, G.A., \& Kirik, G. V. (2016). Compressor stations. Sumy: Sumy State University.

2. Ilin, S. R., Samusia, V. I., Ilina, I. S., \& Ilina, S.S. (2016). Influence of dynamic processes in mine hoists on safety exploitation of shafts with broken geometry. Naukovyi Visnyk Natsionalnoho Hirnychoho Universitetu, 3(153), 42-47.

3. Samusya, V., Oksen, Y., \& Radiuk, M. (2013). Heat pumps for mine water waste heat recovery. Annual Scientific-Technical Collection - Mining of Mineral Deposits, 153-157.

4. Kyrychenko, Y. O., Samusya, V. I., Kyrychenko, V. Y., \& Romanyukov, A. V. (2013). Experimental investigation of aero-hydroelastic instability parameters of the deepwater hydrohoist pipeline. Middle East Journal of Scientific Research, 18(4), 530-534.

5. Compressed Air \& Gas Handbook. $7^{\text {th }}$ ed. (2016). Retrieved from http://www.cagi.org/pdfs/cagi_electhb_ ch1.pdf.

6. Michael, L., \& Stowe, P. E. E. (2017). Compressed Air Basics. American Institute of Chemical Engineers, 4046.

7. Gubaidullin, A., \& Yakovenko, A. (2013). Numerical study of heat exchange of a cylindrical cavity filled with gas under vibration action. Ekaterinburg: Thermophysics and Power Engineering, 207-215.

8. Krichel, S., \& Sawodny, O. (2011). Analysis and optimization of compressed air networks with model-based approaches. Germany: Pnevmatika. Ventil, 334-341.

9. Oksen, Yu., Radyuk, M., \& Samusya, V. (2013). Estimation of economic efficiency of heat pump technology of heat recovery of compressor plants at mining enterprises. Collection of scientific works of the National Mining University, 194-200.

10. Tregubov, V., Zamytsky, O., \& Litovko, B. (2015). Mathematical model of the process of moist air flow through the pipeline. Kryvyi Rih: Collection of scientific works of the Research Mining Institute of the State University “ $K N U$ ”, 55, 288-294.

11. Bondarenko, G., \& Budko, D. (2015). On mathematical modeling of the air supply system of an industrial enterprise. Compressor and power engineering. Sumy: Sumy State University, 4, 29-33.

12. Kumykova, T., \& Kumykov, V. (2013). Investigation of the dynamic characteristics of the mine compressed- 
air hydropneumatic accumulator. Physico-technical problems of mining, 5, 99-109.

\section{Математичне моделювання процесу течії стисненого повітря по трубопроводу як елементу пневмомережі}

\section{О. В. Замицький, Б. М. Літовко, М. Ю. Лідер, М. І. Шепеленко}

Державний вищий навчальний заклад „Криворізький національний університет“, м. Кривий Ріг, Україна, e-mail: azam@i.ua

Мета. Підвищення ефективності експлуатації гірничого обладнання за рахунок підвищення точності розрахунків параметрів стисненого повітря при проектуванні пневматичних мереж.

Методика. У роботі використовувалися теоретичні та емпіричні методи дослідження. Проведене математичне моделювання термогідрогазодинамічних процесів при течії стисненого повітря по трубопроводу. Використовувалися методи математичної статистики.

Результати. Проведене математичне моделювання течії стисненого повітря по трубопроводу, коли температура повітря вище температури навколишнього середовища, що супроводжується відводом тепла до навколишнього середовища й дроселюванням за рахунок опору трубопроводу. У цьому випадку зміна параметрів повітря в потоці залежить від співвідношення змін температури, викликаних відводом теплоти, й тиску через опір трубопроводу. Отримані залежності зміни температури й тиску стисненого повітря по довжині трубопроводу. Експериментальні дослідження й результати чисельних розрахунків підтвердили адекватність математичних моделей течії стисненого повітря по пневмопроводу.

Наукова новизна. Отримані нові залежності для визначення тиску й температури стисненого повітря з урахуванням зміни коефіцієнтів тепловіддачі по довжині пневмопроводу.

Практична значимість. Використання отриманих залежностей при проектуванні пневматичних мереж шахт дозволяе забезпечити вироблення стисненого повітря необхідних параметрів для безперебійного пневмопостачання гірничого обладнання шахт.

Ключові слова: шахтна пневмомережса, стиснене повітря, компресорні установки, трубопровід, пневмоустановки

\section{Математическое моделирование процесса течения сжатого воздуха по трубопроводу как элемента пневмосети}

\author{
О. В. Замыцкий, Б. М. Литовко, М. Ю. Лидер, \\ М. И. Шепеленко
}

Государственное высшее учебное заведение „Криворожский национальный университет“, г. Кривой Рог, Украина, e-mail: azam@i.ua

Цель. Повышение эффективности эксплуатации горного оборудования за счет повышения точности расчетов параметров сжатого воздуха при проектировании пневматических сетей.

Методика. В работе использовались теоретические и эмпирические методы исследования. Проведено математическое моделирование термогидрогазодинамических процессов при течении сжатого воздуха по трубопроводу. Использовались методы математической статистики.

Результаты. Проведено математическое моделирование течения сжатого воздуха по трубопроводу, когда температура воздуха выше температуры окружающей среды, сопровождающегося отводом тепла в окружающую среду и дросселированием за счет сопротивления трубопровода. В этом случае изменение параметров воздуха в потоке зависит от соотношения изменений температуры, вызванных отводом теплоты, и давления из-за сопротивления трубопровода. Получены зависимости изменения температуры и давления сжатого воздуха по длине трубопровода. Экспериментальные исследования и результаты численных расчетов подтвердили адекватность математических моделей течения сжатого воздуха по пневмопроводу.

Научная новизна. Получены новые зависимости для определения давления и температуры сжатого воздуха с учетом изменения коэффициентов теплоотдачи по длине пневмопровода.

Практическая значимость. Использование полученных зависимостей при проектировании пневматических сетей шахт позволяет обеспечить выработку сжатого воздуха необходимых параметров для бесперебойного пневмоснабжения горного оборудования шахт.

Ключевые слова: шахтная пневмосеть, сжатый воздух, компрессорные установки, трубопровод, пневмоустановки

Рекомендовано до публікації докт. техн. наук М.В.Кіяновським. Дата надходження рукопису 05.04.18. 